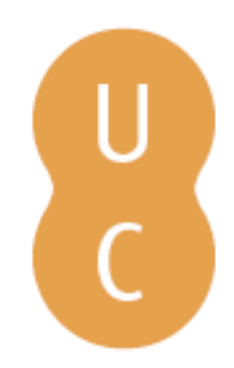

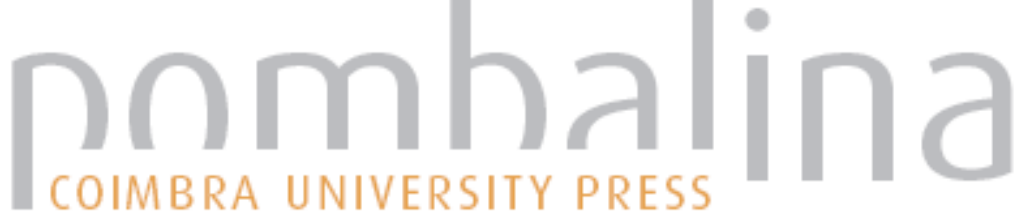

\section{Writing from art}
Autor(es):
Taggart, John
Publicado por: Imprensa da Universidade de Coimbra
URL persistente:
URI:http://hdl.handle.net/10316.2/40000
DOI:
DOI:https://doi.org/10.14195/978-989-26-1115-0_8

Accessed : $\quad$ 26-Apr-2023 14:36:08

A navegação consulta e descarregamento dos títulos inseridos nas Bibliotecas Digitais UC Digitalis, UC Pombalina e UC Impactum, pressupõem a aceitação plena e sem reservas dos Termos e Condições de Uso destas Bibliotecas Digitais, disponíveis em https://digitalis.uc.pt/pt-pt/termos.

Conforme exposto nos referidos Termos e Condições de Uso, o descarregamento de títulos de acesso restrito requer uma licença válida de autorização devendo o utilizador aceder ao(s) documento(s) a partir de um endereço de IP da instituição detentora da supramencionada licença.

Ao utilizador é apenas permitido o descarregamento para uso pessoal, pelo que o emprego do(s) título(s) descarregado(s) para outro fim, designadamente comercial, carece de autorização do respetivo autor ou editor da obra.

Na medida em que todas as obras da UC Digitalis se encontram protegidas pelo Código do Direito de Autor e Direitos Conexos e demais legislação aplicável, toda a cópia, parcial ou total, deste documento, nos casos em que é legalmente admitida, deverá conter ou fazer-se acompanhar por este aviso.

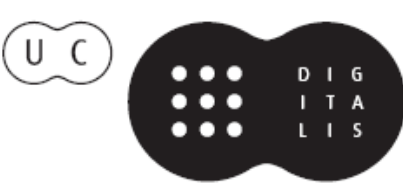




\section{JOÃO CORRÊA-CARDOSO MARIA DO CÉU FIALHO}

(Coordenadores)

\section{A LINGUAGEM NA PÓLIS}

IMPRENSA DA UNIVERSIDADE DE COIMBRA COIMBRA UNIVERSITY PRESS
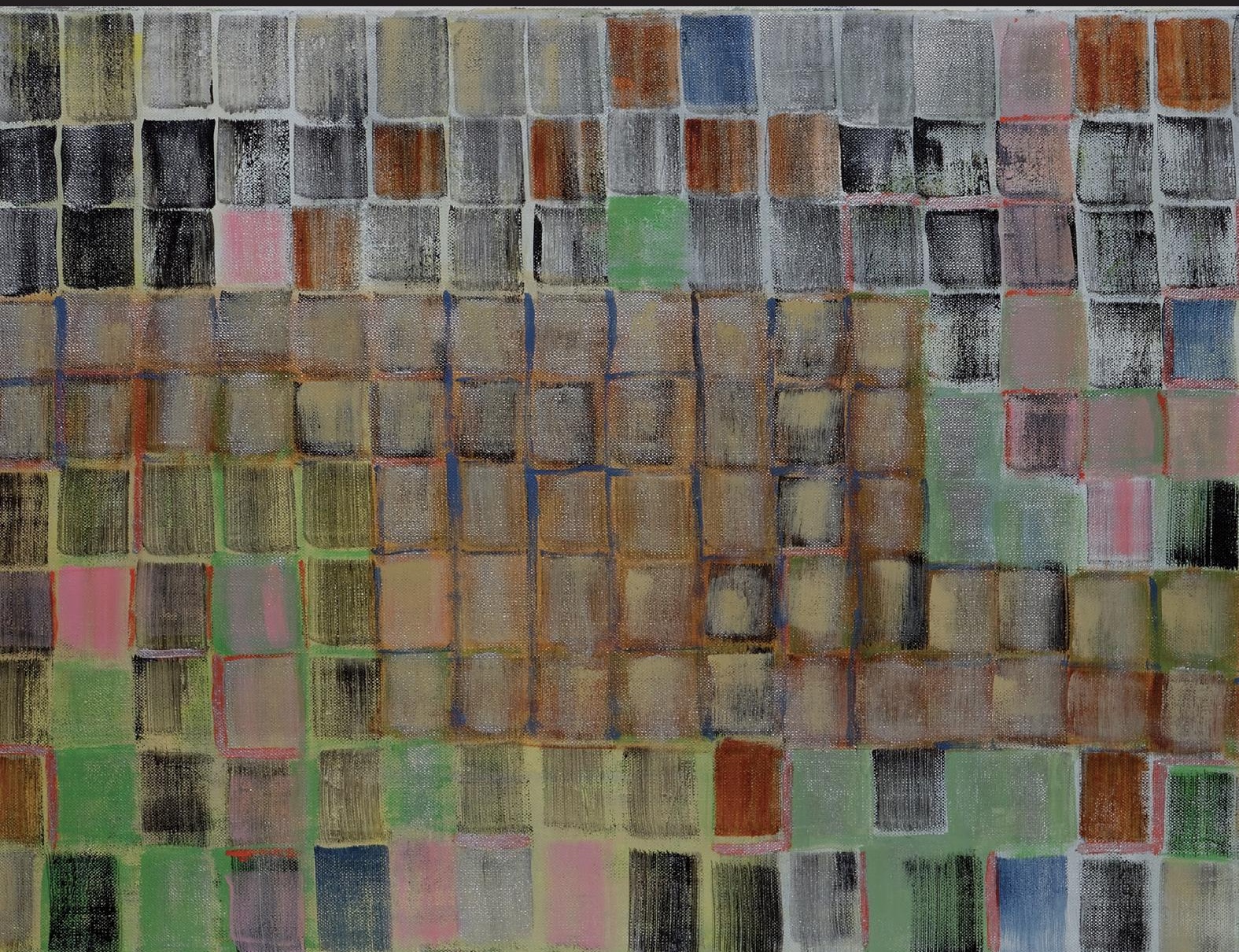


\section{WRITING FROMART}

John Taggart

Poeta em Residência Universidade de Coimbra 2008 jpt@innernet.net

Resumo: Análise intimista sobre as relações entre a poesia, a pintura e a música e o contributo do diálogo interartes na gestão das catástrofes pessoais.

Palavras chave: R. B. Kitaj; John Taggart; poesia; pintura; música; semiótica.

Abstract: Reflections on the complex relationships between poetry, painting and music and their contribution to endure personal loss.

Keywords: R. B. Kitaj; John Taggart; poetry; painting; music; semiotics.

"...poetry and painting, and the arts in general, are, in their measure, a compensation for what has been lost."

Wallace Stevens, "The Relations between Poetry and Painting" 
1. In 1994 the Anglo-American painter R. B. Kitaj suffered two disasters, unanimously hostile critical reaction to a retrospective exhibition of his work at the Tate Gallery and the death of his wife Sandra. He blamed her death on the critics and returned, after nearly forty years in England, to America, the country of his birth. There he began a series of paintings collectively entitled "Los Angeles." The paintings are predominated by depictions of the artist and his wife as nude angels. If a single subject is to be ascribed to the series, from the artist's perspective, it would be loss, mourning loss and attempting some sort of closeness at the same time through the enactment of that mourning in the act of painting. Viewers of these paintings, however, may ascribe to them a larger subject: the hope that death does not mean a separation that remains always and forever a separation from those they love. While Kitaj is a "contemporary" painter (he died in October 2007), this "subject" is both ancient and universal.

2. The challenge of writing from art is transformation. Put as a question: can a poem begin from a painting and end up as a more or less free standing thing-in-itself? More or less because transformation, like translation, is a matter of degree. To translate means to carry something from one place to another. By definition, any sort of writing about or from visual art is a translation. What was made with pigment on a flat two-dimensional surface has been carried over into the signs of language. The question remains whether more than this carrying can be done. Whether more than furniture moving (the sofa remains a sofa, only the rooms are different) can be done. Whether the poem as a composed form made up of linguistic signs (words) can be accomplished-an accomplishment of new meaning-even as it originates from a different, visual form (painting). 
3. There are a number of assumptions involved. Among others: that the poet does not misreport the shape(s) defined by lines and colors of a painting, that the poet is nevertheless attempting to achieve a new form/meaning distinct from or exceeding that of the painter. These assumptions may be complicated, but they are not contradictory. While a poem may be only relatively transformative, it is assumed that transformation is superior to translation even if a poem begins as translation. The test of the latter is verifiability; the test of the former is newness or difference of meaning. This newness or difference may be measured in terms of referentiality. That is, newness or difference $=$ less referentiality, less reporting that is only reporting. It is further assumed that creation of new meaning, no matter how relative its newness may be, is superior to appreciation of the originating source, no matter how "great" that source has been judged to be.

4. A poem can't achieve either translation or transformation unless time is invested in the painting. This investment is prior to the poet's investment in composition, the writing process of the poem. The prior investment involves simply looking at the work and what may be called research. Looking, however, is never simple. An act of attention, it must undergo a discipline of cleansing whereby all those things the observer might like to see or thinks should be seen are dissolved in favor of what is actually there. It is an act which must be repeated (over time). With each repetition comes a reduction of presumption and an increase in understanding. This developing understanding concentrates on elements of form (line, color, texture) and possibilities of meaning suggested by an artist's handling of those elements. Attention is given focus by questions. (Why those lines, why those colors in those particular combinations? What do they suggest?) A questioning, active eye sees more than a passively appreciative eye. Seeing more yields 
the possibility of greater possibilities of meaning (sometimes described as depth).

5. Research always begins in the wrong place, i.e., a source which does not contain information most truly valuable for the poem. As what will prove to be most (or least) valuable can't be known until one is engaged in composition, research should be as far ranging and inclusive as possible. But you can't do research and write a poem at the same time. Hence, again, as far ranging and inclusive as possible prior to writing. In the case of Kitaj, I examined $R$. B. Kitaj:A Retrospective, ed. Richard Morphet and Kitaj In The Aura of Cézanne And Other Masters by Anthony Rudolf and Colin Wiggins. Both books contain reproductions plus commentary and interviews with the painter. I also examined Critical Kitaj, a collection of art historical/critical essays edited by James Aulich and John Lynch. Later, I read the painter's own set of meditations entitled Second Diasporist Manifesto. Research need not be limited to reading. I have benefitted from conversations about Kitaj with my fellow poet Michael Heller, the painter's friend and commentator Anthony Rudolf, his assistant during his last years Tracy Bartley.

6. Research threatens, by its very nature, to lead away from what is primary. It can increase focus and depth, but it can also lead away. In Kitaj's case, one can be led to other painters he admired, especially Cézanne, or to writers he admired, especially Kafka, or to ideas which attracted and obsessed him such as the Jewish question. However fascinating these "secondary sources" may be in themselves, the issue remains whether they contribute to an increase of focus and depth in relation to seeing the painting. How much time is spent with these sources depends upon this issue. Typically, one spends too much time with them only to realize one is gradually seeing at a greater and greater remove 
and through an ever more dark and complicated glass. With that realization comes the awareness that one must stop and return to where one started, the painting itself. There's also the realization that there are way too many stacks of way too many books on your desk. If they fell on you, they could hurt you. Or it's time to begin writing.

7. An instance of this issue in practice is music. In an interview with Colin Wiggins, Kitaj mentions how he listens to jazz while painting. This provides a direction/directive to the poet for his own composition. It is both a way of establishing a sympathy between artist and poet and a way of getting along in the writing process. Jazz is many things. In writing about or from Kitaj, I have listened primarily to Miles Davis and his "Complete Bitches Brew Sessions" 4-cd set. That music-its supercharged, edgy electronic splashiness is much more than merely "colorful"struck me as congruent with Kitaj's "Los Angeles" paintings. It's fair enough to say that this music encouraged and even "pushed" me to develop a like syntax and tone in my poem. Another instance of this issue in practice is my use of language (sometimes in quotation marks, sometimes not) from the poetry of Emily Dickinson. This is based on Kitaj's statement to Wiggins that she was his favorite poet and that his wife's copy of Dickinson's poems was always present in his studio. In some instances, passages from Dickinson act as clues to "passages" in Kitaj. So there is a transaction of passages/images: from the painter's "quotations" of a literary source in his visual work to requotations of that same source in my own non-visual work. Such a transaction may be called intertextual as it may be called interdisciplinary. However that may be, the poet's aspiration-and the musician's and the painter's-is work that in the presentation of a subject is experienced as whole and complete. (This, incidentally, is just 
what got Kitaj in trouble with the critics. Many of the paintings in his retrospective exhibit were accompanied by the artist's commentaries about them. The commentaries implied, by their very nature, that the paintings were neither whole nor complete. Kitaj remains-and perhaps wanted to remain-a complicated and "troublesome" artist.)

8. With these definitions and considerations in mind, let us turn to my poem "Angels No. 1/Kitaj":

Big wings lots of colors

red blue green yellow a pale purple

iris within the colors

raised "fall" of the iris which is saying it with one flower

saying

she angel

splotches/stains on her she angel body

choppy waves around/behind her body terrene and marine angel with

one flower eyes

fruit/grapefruit + berry breasts on not level table dreaming

parts of her dream being split open unrolled

bulbs neon candle-like red thing

two-in-one thing candle-like and the lit up hectic on her cheek bird in flight in her dream.

Most of this is reportage. It reports in a direct, even brusque "in your face" fashion on what's there in the first of Kitaj's "Los Angeles" paintings with particular attention to the female angel figure. Point: the figure is not a generic greeting card angel but an angel with a distinctly and sexually female nude body. Femininity and feminine sexuality are often "signed" as flowers. The poem, 
going from color and shape, designates the flower as an iris. Related colors and shapes are to be found in the figure's wing and eye/eyebrow (the latter is a sign Kitaj borrows from Matisse). The shapes directly above her head are difficult to read. They become less so (and more meaningful) when read in relation to Emily Dickinson:

Split the Lark - and you'll find the Music -

Bulb after Bulb in Silver rolled -

(from poem no. 905, p. 391, The Poems Of Emily Dickinson)

My poem reads her lowered head as dreaming and the shapes above her head as parts of her dream. It is a sexual dream which involves a "neon candle-like red thing" as that which does the splitting. I give such description of the "thing" with regard to its actual appearance in the painting and with a sort of "ghost" reference or quotation from Robert Creeley's poem "The Warning": «For love-I would/split open your head and put/a candle in/behind the eyes." (Yes, Creeley and Kitaj were friends and well aware of one another's work.) A lark is a bird. The blue "swoosh" brush strokes in the painting are read as "bird in flight in her dream."

The second page or part parallels the first with regard to the male angel figure, reporting its corresponding male sexuality (snake-shaped wing, hammer head, strider leg-the last is a "sign" Kitaj borrows from Cézanne). In the painting this male figure is leaning over a table and over the female angel's dream. His one visible eye is covered or "patched." My poem reads his posture as a posture of listening. What he's listening to: "the music" (from Dickinson's poem) given as the bird's song.

Also big also lots

red blue green no yellow and mottled "with mottles 
rare" mottled

with black

shapes one of the shapes of power big black snake him not slim

angel

he angel with an orange ball-peen hammer

head there's some power for you

one strider leg

also splotches/stains but lighter but ochre kind of pink on his angel

leg under the table

he is leaning over her from the other side of the table he is leaning over her dream

eye-patched eye he is listening to "the music" he is listening to bird in flight the song of that bird.

9. The third page or part is an extended improvisation. It elaborates upon the "fictional" situation of the male angel's listening. Like improvisation in jazz, it does not come out of the blue. The male angel is listening to a dream of music conditioned or "colored" by Emily Dickinson's language. A linkage provided by that language gives us an actual song-Hoagy Carmichael's "Skylark"-and, by way of a further linkage, the jazz singer Cassandra Wilson's performance of that song on her "New Moon Daughter" cd. This part reports on some aspects involved with her performance (use of electric bass and pedal steel guitar), and it makes use of some of Carmichael's language. As music, "Skylark" is organized according to an AABA pattern. Part three follows that pattern in its own 
way $(\mathrm{AA}=$ the first two lines which are laid out on the page as separate single line stanzas; $\mathrm{B}=$ the long third stanza; the final A $=$ the closing stanza of two lines which are the same as the first two separate/single stanza lines but which are now combined to form one stanza).

In passing, it should be noted how this part of the poem, i.e., the sound of bass notes, attempts to disturb or agitate both the silence of the painting and the page. This, in fact, is a goal of all my poetry. Like this poem, it contains little or no internal punctuation as a means of defeating the silent reading eye in the interests of encouraging a slowed down, "outloud" engagement with language. That is, the lack of usual or standard punctuation forces a slower/closer reading and perhaps at least some moving of the lips. A poem may utilize other ways to promote a more active engagement with language. One is direct address to the reader as reader, e.g., "if you like adjectives." Another is to use words as words, e.g., the characterizations of the music characterized as "adjectives" in the last two lines of the long third stanza. Is this a "language" poem? Yes and no: yes, it calls attention to language (as language) and no because it wants to do more than that. If you're writing a love poem, a mourning poem, a poem on the birth of a child-any poem of any enduring human significance, you'd better be doing more than calling attention to language.

These characterizations also apply to the situation I take the two angels to be in: one of loss and longing. While the song and its singer are American, the situation is, of course, not restricted to any conception of national identity. Loss and longing are universally human whatever the individual/national flavor or inflection of their expression. (From a Portugese perspective, "Skylark" might be considered a fado song and performed as such.) To cite only one example: the culture of ancient Egypt was based on an attempt to 
deal with loss (death) and provide measures assuring a safe passage to life in the after-life and to a hoped for reunion with those who were loved.

She angel dreaming

he angel leaning over her dream

lutes being old

Fender electric bass slight

sustain

on duuum on single duuum duuums

starts up goes down then up again slightly higher than the start

slightly sustained does this twice goes on doing it

cloud phases scanty pedal steel underlinings along the way

bird in flight music

the music and the words to the music

the words are imploring words imploring where my love might be is there

someone waiting where and is

there the words go on they don't/won't stop

imploring

if you like adjectives it's "wonderful" and "crazy" and "sad" finally

let's face it "American"

dreaming

leaning over her dream.

10. We locate and give identity and meaning to figures by their positions in a scene or "surround" which is often the background of landscape. While there are hints of water around the female an- 
gel figure, what is striking about Kitaj's painting is its background of whiteness. I have chosen to see this background as a realm or region of snow. As something, even a very dangerous something but not nothing and definitely not the "abyss" so beloved of French poets. Even more striking is the single/conjoined arm shared by the two angel figures. Both background and arm are derived from Emily Dickinson.

Foot of the Bold did least attempt it-

It is the White Exploit

Once to achieve, annuls the power

Once to communicate-

(from poem no. 938, p. 400, The Poems Of Emily Dickinson)

On that dear Frame the Years had worn

Yet precious as the House

In which We first experienced Light

The Witnessing, to Us-

Precious! It was conceiveless fair

As hands the Grave had grimed

Should softly place within our own,

Denying that they died.

(from poem no. 924, p. 396, The Poems Of Emily Dickinson)

It should be noted that my reading of Kitaj's whiteness differs from the painter's own reading of Dickinson. (See In The Aura, p. 26, where he gives "white exploit" as her term for death.) Or I transpose the word "exploit" (meaning a brilliant or daring achievement) to refer to their "one long arm," which is surely a brilliant and daring enough new sign on the painter's part 
for the ancient human hope of union, of reunion with those we love after separation and not only death's separation. My own image/sign is of a more modest nature. Keeping to a fairly matter of fact report (of the colors on their two-in-one long arm), it places them/their arm against and in contrast with the snow, which is a realm/region of anxiety wherein two travellers may get lost and lose one another. Kierkegaard may be right to consider anxiety as a concept, but-if you have it or have been "had" by it-the anxiety of separation that remains always and forever separation can also be an actuality that haunts every day of your life. By this juxtaposition/contrast-an image-the poem attempts to render the hope (and faith) embodied by that sign as an achievement that will stand up to and may transcend death's "achievement."

In the realm/region of the

possible of possibility and anxiety because

of possibility

hand

in his he angel hand

realm/region of snow in which huddled cattle freeze in which two travelers may get lost may

lose one another call and call to one another

hand bones connected to arm bones arm in arm one long arm bone

ochre kind of pink all suffused

of feedback 
crackles grainy buzz/fuzz

feedback after there is silence and there is silence

she is dreaming he is leaning/listening she and he who are one arm

are ochre kind of pink exploit in the snow. 